\title{
The Case Study of Cross-Shareholding between ZHENYE and CHANGCHENG
}

\author{
Jialing Liu \\ Management School, Jinan University, Guangzhou, China \\ Email: liu_jialing93@sina.com
}

How to cite this paper: Liu, J.L. (2019) The Case Study of Cross-Shareholding between ZHENYE and CHANGCHENG. American Journal of Industrial and Business Management, 9, 342-353.

https://doi.org/10.4236/ajibm.2019.92023

Received: January 16, 2019

Accepted: February 24, 2019

Published: February 27, 2019

Copyright (c) 2019 by author(s) and Scientific Research Publishing Inc. This work is licensed under the Creative Commons Attribution International License (CC BY 4.0).

http://creativecommons.org/licenses/by/4.0/

(c) (i) Open Access

\begin{abstract}
The phenomenon of cross-shareholding in China was formed in the 1990s. Domestic and foreign scholars have studied the motives and effects of the formation of cross-shareholding system, but there are few specific case studies, especially the cross-shareholding formed by the government. Therefore, this paper will study the cross-shareholding case. Shenzhen Zhenye (Group) Co., Ltd. ("ZHENYE" for short) and Shenzhen Changcheng Investment Holding Co., Ltd. ("CHANGCHENG" for short) held each other's shares from 1995 to 2013, which lasted 18 years. This cross-shareholdings relationship promoted by the government brought both positive and negative effects to ZHENYE. This article analyzes the effects to ZHENYE and give suggestions to the cross-shareholdings companies: 1) in order to prevent hostile takeover, the cross-shareholdings companies should consider the percentage of cross-shareholdings or cooperate with more than one company; 2) making an alliance with other companies will benefit the long-term development of the company; 3 ) cross-shareholdings can be a new way of transformation of the state-owned enterprises.
\end{abstract}

\section{Keywords}

Cross-Shareholding, Cross-Shareholding Effects, Cross-Shareholding Motivations

\section{Introduction}

Cross-shareholding is a special form of equity structure, which refers to a mutual shareholding phenomenon in which two or more companies invest in each other's stocks. The cross-shareholding companies usually form a shareholding structure of "you own my equity and I own your equity" because of the need of business or investment. 
The cross-shareholding system was originated in Japan after World War II. Under the threat of highly dispersed shares and foreign acquisitions, the cross-shareholding system became an effective means of resisting hostile takeovers of foreign capital. From 1975 to 1989, the cross-shareholding of Japanese companies reached its peak. However, during the subsequent economic recession in Japan, it played a role in fueling the stock market bubble.

China's cross-shareholding phenomenon appeared late and was formed in the 1990s. China's earliest cross-shareholding originated from the government's guidance. After 2005, with the promotion of the share-trading reform, more and more non-tradable shares were converted into tradable shares, and crossshareholding behavior became active. Cross-shareholding can form corporate alliances [1], stable stock price [2], and promote enterprise development, but also there are problems such as increasing capital [3] and harming the interests of minority shareholders. Cross-shareholding has an increasing influence on China's capital market. Scholars' research on cross-shareholding is also deepening, and researches on the motives and effects of cross-shareholding, but domestic research mainly focuses on theoretical research. However, the research on case studies, especially the number of cross-shareholding research initiated by the government, is small, so this paper will study the cross-shareholding cases of Shenzhen Zhenye (Group) Co., Ltd. ("ZHENYE” for short) and Shenzhen Changcheng Investment Holding Co., Ltd. (“CHANGCHENG” for short). This paper has both theoretical and practical significance. In theory, our research will enrich the literature on cross-shareholding research. In practice, our research can provide advices for cross-shareholding companies.

In the second part of this paper, we will briefly introduce the current status of cross-shareholding in China. In the third part, we will analyze in detail the process, positive influences and negative influences of ZHENYE and CHANGCHENG cross-shareholding. In the fourth part, we will make some suggestions to the cross-shareholding companies based on the case of ZHENYE and CHANGCHENG cross-shareholding. Finally, we will summarize the article.

\section{The Status Quo of Cross-Shareholding in China}

Fang, H. K., Jiang, Z. H. and Wang, Y. K. (2018) [4] count the cross-shareholding data of Chinese listed companies in 2017. They find that 673 listed companies have different levels of cross-shareholding behavior, and listed companies with cross-shareholdings account for $18.75 \%$ of the total.

According to the statistics of 2017, the number of cross-shareholdings of listed companies in China varies greatly in regions and industries. Figure 1 shows the top nine cross-shareholding areas of listed companies in 2017. The largest number of listed companies participating in cross-shareholdings is Shanghai, accounting for $24 \%$, followed by Guangdong and Beijing. As can be seen from the figure, the top five account for the majority, and four of them are located in the coastal areas. It can be inferred that the superior geographical position and the 


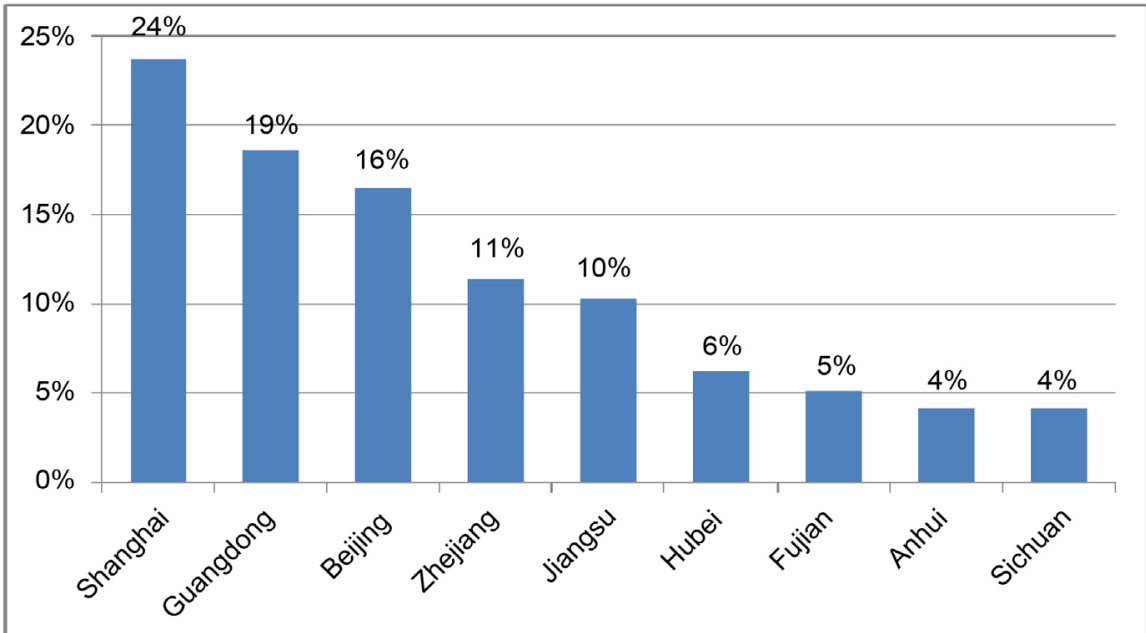

Figure 1. The top nine cross-shareholding areas of listed companies in 2017. The data comes from Analysis of Cross-shareholding of Listed Companies-Taking Suning and $B A B A$ as Examples [4].

developed economy provide convenience for the cross-shareholding of enterprises. Figure 2 shows the industry distribution of cross-shareholdings of listed companies in 2017. The largest number of listed companies participating in cross-shareholdings is manufacturing, accounting for $42.73 \%$, followed by the wholesale and retail and real estate industries. This is related to the relatively mature development of China's manufacturing market.

\section{Case Overview}

\subsection{Background of Case Companies}

ZHENYE (stock code: 000006), founded in 1989, is a state-owned enterprise directly under Shenzhen State-owned Assets Supervision and Administration Commission ("Shenzhen SASAC" for short). Its main business is real estate development and operation. The company's business scope covers land development, property sales, leasing and property management. It has been awarded the title of Top 100 Real Estate Companies in China and Top 100 Listed Companies in China. The ZHENYE property rights and control relationship chart on December 31, 2012 is shown in Figure 3.

CHANGCHENG (stock code: 000042, renamed as "Shenzhen Zhongzhou Investment Holding Co., Ltd.” in 2014) was established in 1984. Its main business is real estate development and operation. The company's business scope covers real estate development and commercial housing sales management, construction and installation projects, self-owned property leasing and hotel operations. It is among the first to obtain the first-class qualifications for national real estate development.

\subsection{The Process of Cross-Shareholdings}

ZHENYE was founded by CHANGCHENG and two other companies. 


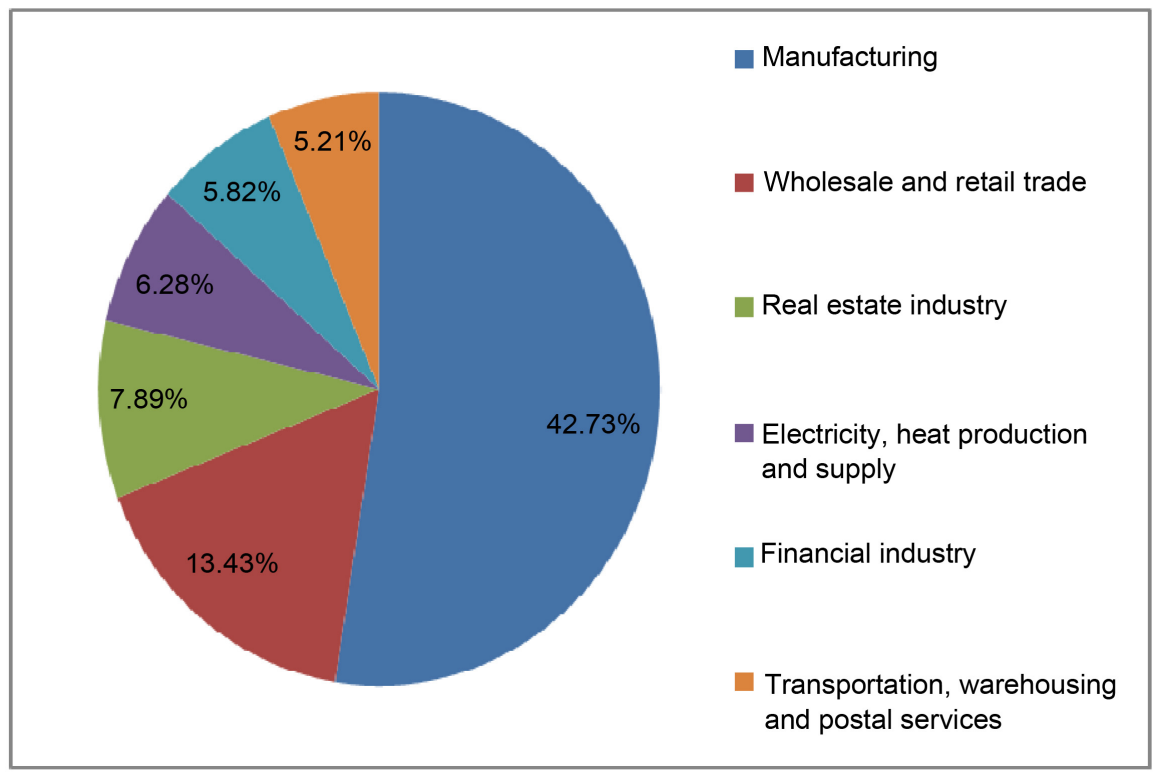

Figure 2. The industry distribution of cross-shareholdings of listed companies in 2017. The data comes from Analysis of Cross-shareholding of Listed Companies-Taking Suning and $B A B A$ as Examples [4].

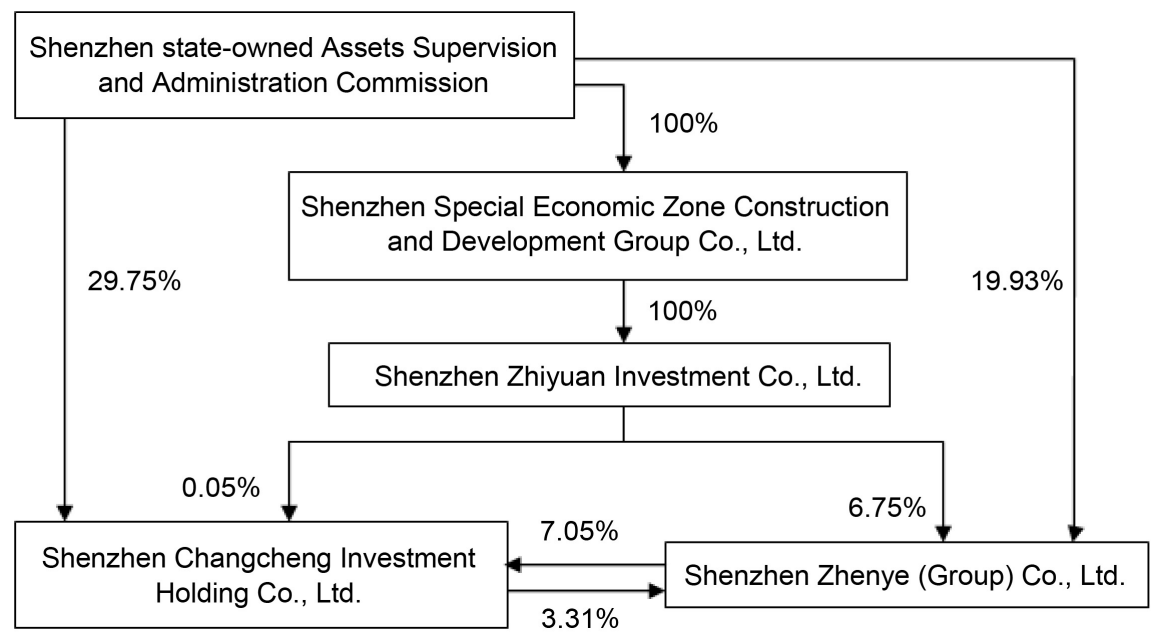

Figure 3. Relationship between ZHENYE and CHANGCHENG property rights and control on December 31, 2012. The information is from the CHANGCHENG 2012 Annual Report.

CHANGCHENG, as one of the founders of ZHENYE, held its shares at the beginning of ZHENYE's listing. ZHENYE's 1992 annual report showed that CHANCHENG held $3.98 \%$ of its shares.

In December 1995 and February 1996, ZHENYE agreed to acquire 8.25\% of CHANGCHENG's shares. Since then, ZHENYE has formed a cross-shareholding relationship with CHANGCHENG.

In January 2006, ZHENYE implemented the share-trading reform. CHANGCHENG paid part of its ZHENYE shares as the consideration to the original tradable shareholders, and CHANGCHENG held ZHENYE shares 
down to $3.31 \%$.

In August 2006, CHANGCHENG implemented the share-trading reform. ZHENYE paid part of the CHANGCHENG shares it held as the consideration to the original tradable shareholders. ZHENYE held the CHANGCHENG shares down to $7.05 \%$.

In March 2013, CHANGCHENG transferred 3.31\% of all ZHENYE shares held by itself.

From August 2014 to October 8, 2014, ZHENYE reduced its holding of all the 7.05\% shares of CHANGCHENG through the block trading system. At this point, both ZHENYE and CHANGCHENG no longer held each other's shares.

From 1995 to 2013, ZHENYE and CHANGCHENG held cross-shareholdings for 18 years. The changes in cross-shareholdings in each year are shown in Table 1.

\section{Case Study}

\subsection{The Motivation of Cross-Shareholding}

In the early 1990s, in order to deepen the reform of state-owned enterprises and realize the diversification of equity, the government guided enterprises to cross-share. Liaoning Cheng Da Co., Ltd. and GF Securities Co., Ltd. were typical cases of cross-shareholding in that period [1]. ZHENYE and CHANGCHENG were also the intersections formed during that period.

ZHENYE and CHANGCHENG began to cross-share in 1995, when both were local state-owned enterprises controlled by Shenzhen Construction Investment Holding Co., Ltd., and ZHENYE accepted the transfer of CHANGCHENG shares by Shenzhen Construction Investment Holding Co., Ltd. as a transferee to form a cross shareholding relationship. It can be seen that the cross-shareholding between ZHENYE and CHANGCHENG was promoted by the government. Therefore, it is speculated that Shenzhen Construction Investment Holding Co., Ltd. is to separate control and cash flow rights. Simultaneously, it would control the two companies and carry out capital expansion with less capital [5].

\subsection{Positive Influences}

\subsubsection{Cash Dividend Distribution Policy Brings Cash Inflows to Cross-Shareholding Companies}

ZHENYE recognizes the shares of CHANGCHENG as available-for-sale financial assets. During the period of holding the shares, the change in the fair value of the

Table 1. The changes in cross-shareholdings between ZHENYE and CHANGCHENG.

\begin{tabular}{|c|c|c|c|c|}
\hline Year & 1995-1996 & 1997-2005 & 2006-2012 & 2013 \\
\hline $\begin{array}{l}\text { Proportion of CHANGCHENG shares held } \\
\text { by ZHENYE }\end{array}$ & $8.25 \%$ & $8.25 \%$ & $7.05 \%$ & $7.05 \%$ \\
\hline $\begin{array}{l}\text { Proportion of ZHENYE shares held by } \\
\text { CHANGCHENG }\end{array}$ & $3.98 \%$ & $4.94 \%$ & $3.31 \%$ & $0.00 \%$ \\
\hline
\end{tabular}

Note: The data comes from the company's annual report for each year, and the form is compiled by the author. 
shares is included in the "other comprehensive income" subject. When the shares held are sold, they will be counted. The accumulated gains and losses from the accumulated fair value of the "other comprehensive income" account are transferred to the "investment income" account. During the holding of CHANGCHENG stock by ZHENYE, the changes of CHANGCHENG stock price will not be reflected in ZHENYE's income statement. The impact on ZHENYE's profit is the cash dividend distributed by CHANGCHENG.

From 2007 to 2012, CHANGCHENG had carried out cash dividend distribution. Table 2 lists the dividend amount obtained by ZHENYE in each year. It can be seen that the dividend amount accounts for a small proportion of the net profit attributable to shareholders of the listed company, indicating that CHANGCHENG's dividends have little impact on ZHENYE's earnings. In addition, the cash inflows from investment activities in 2011 and 2012 were almost always caused by the amount of dividends. When the company's short-term debt repayment pressure is high, the cash inflow from dividends can alleviate the company's financial pressure to some extent.

\subsubsection{Circulate Necessary Funds}

The development of real estate enterprises will be affected by the government's macroeconomic policies. Since the housing prices increasing in 2004, the government began to strengthen the regulation of the real estate market. The regulation of macroeconomic policies and the tightening of monetary policy had caused the real estate industry to generate greater financing pressure. In 2010, in order to curb the momentum of excessive housing price increases, several cities had successively introduced a purchase restriction policy. From 2011 to 2012, the government maintained macro-control of the real estate industry, and the overall inventory level of the industry remained high. The government's macroeconomic regulation had slowed down the development of the real estate industry to a certain extent. The tightening of monetary policy had made the real estate industry more difficult to finance, and enterprises had the need to seek funding sources.

Table 2. ZHENYE's investment income from holding CHANGCHENG's shares during 2007-2012.

\begin{tabular}{cccc}
\hline Year & $\begin{array}{c}\text { Last year's dividend } \\
\text { (Yuan) }\end{array}$ & $\begin{array}{c}\text { Proportion of net profit } \\
\text { attributable to shareholders } \\
\text { of listed companies }\end{array}$ & $\begin{array}{c}\text { Proportion of cash } \\
\text { inflows from } \\
\text { investment activities }\end{array}$ \\
\hline 2007 & $3,039,132.24$ & $1.18 \%$ & $4.34 \%$ \\
2008 & $3,376,813.60$ & $2.25 \%$ & $56.98 \%$ \\
2009 & $337,681.36$ & $0.10 \%$ & $0.22 \%$ \\
2010 & $2,532,610.20$ & $0.53 \%$ & $5.94 \%$ \\
2011 & $10,130,440.80$ & $2.33 \%$ & $99.34 \%$ \\
2012 & $6,753,627.20$ & $1.09 \%$ & $91.91 \%$ \\
\hline
\end{tabular}

Note: This table is organized by the author. 
Under the control of macroeconomic policies, the overall development of the industry has slowed down, and the income from holding equity in the same industry can be limited. The transfer of shares in the same industry can enhance the company's financial strength to a certain extent in a relatively short period of time. In this high-pressure situation, the allocation of limited cash inflows to more efficient projects can effectively improve the overall asset utilization of the company.

Table 3 shows the short-term borrowings of ZHENYE from 2011 to 2013 and the total non-current liabilities due within one year. As of the end of 2011, ZHENYE needed to repay short-term loans and non-current liabilities due within one year to a total of 1.75 billion Yuan, but the quick ratio was only 0.1558. In 2012, it was under great pressure to repay the borrowing funds, and it wanted to sell the shares held by CHANGCHENG. One of the purposes was to increase the company's cash inflow. If it could successfully sell its CHANGCHENG shares, it was expected to increase the cash inflow of 237 million Yuan in the year to ease the company's financial pressure, so as to concentrate resources to accelerate the development of the main business and promote its follow-up development.

In addition to the transfer of the sale of shares, the pledge of the shares held by the shares can also bring in cash inflows [6]. In 2009, ZHENYE pledged the shares of CHANGCHENG to obtain a loan guarantee of 700 million Yuan, which provided strong support for its real estate development business. Cross-shareholding is conducive to stabilizing stock prices, while high stock prices can bring more pledge loans to enterprises and bring more funds to enterprises. This behavior is more common in the parent-subsidiary cross-shareholding model.

\subsection{Negative Influences}

\subsubsection{Limited Role in Preventing Acquisitions}

The cross-shareholding system originated in Japan and played an important role in preventing Japanese companies from being maliciously acquired by foreign capital. It has the positive effect of preventing enterprises from being merged. However, ZHENYE and CHANGCHENG were both placarded by private capital during the cross-shareholding period.

In June 2010, Baoneng (the company or affiliate of Shenzhen Baoneng Investment Group Co., Ltd.) began to invest in ZHENYE. By March 2012, Baoneng had a shareholding ratio of $15 \%$ and three seats on ZHENYE's board of

Table 3. ZHENYE's short-term borrowings and total non-current liabilities due within one year from 2011 to 2013 (unit: Yuan).

\begin{tabular}{cccc}
\hline & 2011 & 2012 & 2013 \\
\hline ZHENYE & $1,750,000,000$ & $50,000,000$ & $500,000,000$ \\
\hline
\end{tabular}

Note: The data comes from the company's annual report for each year, and the form is compiled by the author. 
directors ( 9 board members, including 3 independent directors), two of whom were independent director, and one independent director. Baoneng wanted to compete for the controlling stake in ZHENYE. The Shenzhen SASAC and Shenzhen Zhiyuan Investment Co., Ltd. (“Zhiyuan” for short) responded by holding multiple controlling capitals to increase their shareholdings. In the end, Shenzhen SASAC and Zhiyuan and CHANGCHENG held a total of $30 \%$ shares of ZHENYE to strengthen the controlling interest in ZHENYE. In addition, in June 2013, the retail investor Ma Xinqi held a 5\% stake in ZHENYE. In order to prevent the cooperation between Ma Xinqi and Baoneng from threatening the controlling stake of Shenzhen SASAC, Shenzhen SASAC and Zhiyuan once again increased their shareholding in ZHENYE. The two held a total of $30.363 \%$ shares, which eventually led Baoeng to withdraw from the control of the controlling share.

Cross-shareholding can indeed play a role in preventing companies from being merged. Cross-shareholding companies can form a coalition relationship. When the company is exposed to external acquisition risks, a stable alliance relationship can stabilize the stock price, and the company as an alliance refuses to sell the stock to the acquirer, thereby making the purchaser purchase cost increase and abandon the acquisition. When ZHENYE was subject to the risk of being acquired, the increase in holding behavior of Shenzhen SASAC and Zhiyuan played a key role in preventing the acquisition. Although ZHENYE and CHANGCHENG had cross-shareholdings but had a small shareholding ratio, CHANGCHENG only held ZHENYE $3.31 \%$ of the shares, when the capital-sufficient placards hold up to $15 \%$ of the shares, such a small proportion of cross-shareholding alliances had little effect on preventing acquisitions. In addition, CHANGCHENG was also exposed to the risk of being acquired during the cross-shareholding period, which also shows that a small proportion of cross-shareholdings have a limited role in preventing acquisitions.

\subsubsection{Cross-Shareholding Brings the Problem of Horizontal Competition} Horizontal competition means that "the business of a listed company is the same or similar to the business of the controlling shareholder, the actual controller and the enterprise controlled by it, and the two parties constitute or may constitute a direct or indirect competitive relationship". China has provisions on prohibiting horizontal competition in the listing of companies and the governance of listed companies: Article 19 of the Measures for the Administration of Initial Public Offerings and Listings promulgated by the China Securities Regulatory Commission on May 17, 2006 stipulates that "The issuer's business shall be independent of the controlling shareholder, the actual controller and other enterprises controlled by it, and there shall be no horizontal competition or unfair related party transactions with the controlling shareholder, the actual controller and other enterprises controlled by it (Decision on Amending the Measures for the Administration of Initial Public Offerings and Listings, which was imple- 
mented on January 1, 2016, has deleted this article)"; Article 27 of the "Guidelines for the Governance of Listed Companies" promulgated and implemented on January 7, 2002 stipulates that "the business of a listed company shall be completely independent of the controlling shareholder; the controlling shareholder and other units under its control shall not engage in the same or similarity as the listed company business; controlling shareholders should take effective measures to avoid horizontal competition."

The controlling shareholders of ZHENYE and CHANGCHENG were both Shenzhen SASAC (between 2006 and 2013), and there were real estate development and sales, property leasing management, etc. in the main business. There was horizontal competition between the companies. The horizontal competition between ZHENYE and CHANGCHENG was caused by historical reasons. Both of them were listed in the 1990s. ZHENYE and CHANGCHENG began to form a cross-holding relationship in 1995 and there was a problem of horizontal competition since 1995.

The controlling shareholders have limited capital in their hands. With the cross-shareholding relationship, the controlling shareholder can use less capital to obtain the controlling rights of several companies at the same time. But also because the controlling shareholders have limited capital, when their companies have horizontal competition, they may use the power of control to allocate resources in a biased manner between enterprises. This practice may affect the normal development of listed companies and harm the interests of minority shareholders [7].

Both ZHENYE and CHANGCHENG are real estate companies. The business of CHANGCHENG also involves hotel operations. In comparison, ZHENYE's business is more concentrated. As the controlling shareholder of ZHENYE and CHANGCHENG, the Shenzhen SASAC has limited resources. When it is necessary to allocate resources between the two real estate companies, there must be some concerns, just as the two companies are simultaneously subject to the risk of being acquired. The Shenzhen SASAC should choose between the two. In the end, the Shenzhen SASAC transferred most of the shares of CHANGCHENG to private capital, thus solving the long-standing horizontal competition between ZHENYE and CHANGCHENG.

\subsubsection{Cross-Shareholding Brings Inflated Capital Problems}

In the cross-shareholding relationship, the same funds were circulated between ZHENYE and CHANGCHENG. This capital also increased the double calculation of the capital generated by the two companies, which would inflate the corporate capital. In addition, ZHENYE recognized the shares of CHANGCHENG held as available-for-sale financial assets, and increased the owner's equity of ZHENYE when the stock price of CHANGCHENG rose. When creditors evaluate the strength of a company, it may be misled by the inflated capital, which may damage the interests of the creditor. 


\section{Suggestions}

\subsection{Increase Cross-Shareholding Ratio or Alliance with Multiple Companies to Prevent Hostile Takeovers}

The cross-shareholding system enables companies to form alliances, expand their scale, strengthen their capital, and prevent hostile takeovers. However, from ZHENYE and CHANGCHENG, it can be seen that a small proportion of cross-shareholdings has a limited role in preventing acquisitions. Cross-shareholding can indeed play a role in preventing companies from being merged. This effect is mainly reflected in two aspects: First, cross-shareholding companies can form a coalition relationship. When the company is exposed to external hostile takeover risks, a stable alliance relationship can stabilize the stock price and make the acquirer's expected acquisition cost too high to abandon the acquisition. Second, as a party in the alliance relationship, it does not sell the shares it holds to the acquirer, forming a "white knight", making it difficult for the acquirer to acquire, thus making it prohibitive.

The ratio of ZHENYE and CHANGCHENG cross-shareholding was only $7.05 \%$ and $3.31 \%$. When the capital-rich purchaser increased the company's shares through the secondary market to reach $15 \%$, the above two aspects had little effect on them. Therefore, if you want to use cross-shareholding as a means to prevent the purpose of acquisition, then you must consider how much the shareholding ratio can play a better role. In addition, companies can form alliances with multiple companies at the same time to form a complex cross-shareholding relationship. When faced with acquisition risks, a complex corporate alliance network can play a greater role than a small proportion of direct cross-shareholdings such as ZHENYE and CHANGCHENG.

In addition, cross-shareholdings must also take into account potential risks. For example, when the stock market declines, cross-shareholding will form a drag-down effect. At this time, cross-shareholding companies are more likely to become targets of acquisition.

\subsection{A Strategic Cross-Shareholding Relationship Should Be Established between Enterprises for Long-Term Cooperation}

Although ZHENYE and CHANGCHENG have a cross-shareholding time of 18 years, the relationship between them is relatively loose. During the crossshareholding period, they mainly obtained investment income, and there was little strategic cooperation. Therefore, the type of cross-shareholding they had was similar to many short-term financial cross-holdings that captures temporary investment income or stock spreads.

Financial cross-shareholding is more of a speculative act than a strategic cross-shareholding that cross-shares for long-term strategic cooperation. This loose relationship may bring short-term benefits to the company, and may also cause the company's investment to fail. The strategic cross-shareholding brings a closer long-term cooperative alliance between enterprises. In addition to the 
relationship between capital and property rights, enterprises can form strategic alliances, thereby expanding the scale of enterprises, optimizing resource allocation, improving the competitiveness of enterprises, and ultimately achieving multi-win.

Both ZHENYE and CHANGCHENG are real estate companies. After years of development, ZHENYE has better qualifications. In this cross-shareholding relationship, Shenzhen SASAC consolidated its controlling stake in ZHENYE with better qualifications with limited resources, and sold the controlling share of CHANGCHENG. Although this cross-shareholding relationship was passively formed by the government, if the two companies could establish strategic partnerships during cross-shareholding, form a community of interests, exchange funds and manage resources [8], and optimize resource allocation, rather than just as competitors in the same industry the economic benefits would be higher than the cash dividends obtained, and would benefit the long-term development of the companies.

\subsection{Cross-Shareholding Can Be Used as a New Way of Reforming State-Owned Enterprises}

In order to deepen the reform of state-owned enterprises and realize equity diversification in the 1990s [9], the government guided enterprises to cross-share. The cross-shareholding relationship between ZHENYE and CHANGCHENG was promoted by the government, but the positive effects brought about during the cross-shareholding period were not obvious. So is this model useful for reference in the process of state-owned enterprise reform? The answer is yes.

ZHENYE and CHANGCHENG were cross-shareholding relationships of financial companies in the same industry. They did not form a strategic partnership and there were also problems of horizontal competition. Therefore, the positive effects of cross-shareholding were hard to come by. If they could carry out cross-industry strategic cross-shareholding, then these constraints would not work. For example, in February 2016, WISCO and China State Shipbuilding Co., Ltd. announced that their respective controlling shareholders intend to transfer part of the shares to COSCO Group without compensation. If the transfer is completed, cooperation between upstream and downstream enterprises of steel, ships and shipping will be formed. The cross-institutional cross-industry of these three companies is not a simple financial investment behavior, but can promote business collaboration and industry chain integration between enterprises. Such behavior will reflect the positive effects of cross-shares and also inject new vitality into the reform of state-owned enterprises.

\section{Conclusion}

ZHENYE and CHANGCHENG obtained cash inflows and financing funds during the cross-shareholding period, but could not solve the problem of inflated capital and horizontal competition, and played a limited role in resisting hostile 
takeovers. The case of ZHENYE and CHANGCHENG cross-shareholding can provide reference for other cross-shareholding companies. Firstly, if companies want to achieve the purpose of resisting hostile takeovers through crossshareholding, they must consider how much shareholding ratio can play a better role. In addition, companies can form alliances with multiple companies at the same time to form a complex cross-shareholding relationship. When faced with acquisition risks, a complex corporate alliance network can play a greater role than a small proportion of direct cross-shareholdings. Secondly, the company's strategic cross-shareholding is more conducive to the advantages of crossshareholding. During cross-shareholding period, companies can establish strategic partnerships, form a community of interests, exchange funds and manage resources [8], and optimize resource allocation, which is beneficial to the longterm development of the companies. Finally, cross-shareholding can serve as a new way of reforming state-owned enterprises.

\section{Conflicts of Interest}

The author declares no conflicts of interest regarding the publication of this paper.

\section{References}

[1] Chu, Y.Y. and Wang, W.Z. (2001) Thoughts on the First Case of Interactive Shareholding in China. Management World, 5, 173-186

[2] Pei, G.F. (2008) Thoughts on Cross-Shareholding of Chinese Listed Companies-From the Cross-shareholding in Japan. Social Sciences In Guangdong, 4, 40-44

[3] Ferguson, R. and Hitzig, N.B. (1993) How to Get Rich Quick Using GAAP. Financial Analysts Journal, 49, 30-34. https://doi.org/10.2469/faj.v49.n3.30

[4] Fang, H.K., Jiang, Z.H. and Wang, Y.K. (2018) Analysis of Cross-shareholding of Listed Companies-Taking Suning and BABA as Examples. Economic Management (Abstract Edition), 5, 358-360.

[5] La Porta, R., Lopez-De-Silanes, F. and Shleifer, A. (1999) Corporate Ownership around the World. The Journal of Finance, 54, 471-517. https://doi.org/10.1111/0022-1082.00115

[6] Jiang, X.Y. (2009) Research on Legal Regulation of Cross-Shareholding in Listed Companies. Shenzhen Stock Exchange Research Institute, Shenzhen.

[7] Lu, Z.F. and Wang, P. (2013) Horizontal Competition, Earnings Management and Transfer of Controlling Shareholders' Interests. Journal of Financial Research, 6, 179-192.

[8] Chen, Q.M. (2014) The Mechanism and Economic Consequences of Cross-Shareholding. Social Sciences Academic Press, Beijing.

[9] Chu, Y.Y. (2007) Literature Review and Research Outlook on Cross Holding. Journal of Shanghai Lixin University of Commerce, 21, 25-31. 